\title{
PEMBELAJARAN PROJECT BASED LEARNING PADA KOMPETENSI LAS LISTRIK BERBASIS PRODUK DI SMK PEMESINAN
}

\author{
Muhammad Imam Widya A ${ }^{1}$, Wahid Munawar ${ }^{2}$, Asep H. Sasmita ${ }^{3}$ \\ Departemen Pendidikan Teknik Mesin \\ Universitas Pendidikan Indonesia \\ Jl. Dr. Setiabudhi No. 207 Bandung 40154 \\ m.imamwidya@yahoo.com
}

\begin{abstract}
ABSTRAK
Tujuan penelitian ini untuk mendeskripsikan pelaksanaan pembelajaran kompetensi las listrik dengan menggunakan model PjBL ketercapaian waktu yang dihasilkan siswa dalam membuat produk, mendeskripsikan kompetensi las listrik yang dihasilkan siswa, dan mendeskripsikan ketercapaian pembuatan produk.Metode yang digunakan pada penelitian ini adalah pre-eksperimental dan desain peneliatiannya adalah one shot case study. Lokasi penelitian ini di SMKN 1 Katapang, populasi penelitian ini adalah siswa kelas X MP 2 SMKN 1 Katapang yang berjumlah 36 orang, dan yang dijadikan sampel adalah 6 orang siswa dari kelas X MP 2. Teknik pengambilan sampel yang digunakan ialah teknik sampling purposive. Teknik pengumpulan data menggunakan tes kinerja dan teknik analisis data dengan menggunakan Content Validity Rasio (CVR) dan Content Validity Index (CVI). Hasil dari penelitian ini adalah pelaksanaan pembelajaran kompetensi las listrik dilaksanakan dengan beberapa tahap yaitu penentuan pertanyaan mendasar, perencanaan proyek, menyusun jadwal, monitoring, menguji hasil dan evaluasi pengalaman. Ketercapaian waktu pembuatan produk yang dihasilkan seluruh kelompok dinyatakan lulus karena tidak melebihi dari alokasi waktu pembelajaran.
\end{abstract}

Kata kunci: PjBL, las listrik, produk, pemesinan

\section{PENDAHULUAN}

Latar belakang masalah penelitian ini adalah tuntutan pada Kurikulum 2013 khususnya pada metode pembelajaran yang berpusat pada peserta didik (student centered) dan menekankan menggunakan model pembelajaran dengan pendekatan saintifik. Metode pembelajaran kompetensi las listrik yang masih bersifat teacher centered dan model pembelajaran yang hanya mengajarkan teknik dasar pengelasannya saja (Abidin, 2014). Pada saat praktek pengelasan banyak siswa yang mengantri untuk bergantian menggunakan mesin las listrik karena mesin las listrik yang terbatas.

Permendikbud 2014 tentang pendidikan di Indonesia yang menjelaskan keterampilan diperoleh melalui kegiatan mengamati, menanya, mencoba, menalar, menyaji, dan mencipta. Seluruh isi materi (topik dan subtopik) mata pelajaran yang diturunkan dari keterampilan harus mendorong siswa untuk melakukan proses pengamatan hingga penciptaan (Aunurrahman, 2013). Mewujudkan keterampilan tersebut perlu melakukan pembelajaran yang menerapkan modus belajar berbasis penelitian

\footnotetext{
${ }^{1}$ Mahasiswa Departemen Pendidikan Teknik Mesin FPTK UPI

${ }^{2}$ Dosen Departemen Pendidikan Teknik Mesin FPTK UPI

${ }^{3}$ Dosen Departemen Pendidikan Teknik Mesin FPTK UPI
} 
(discovery/inquiry learning). Pembelajaran yang menghasilkan karya berbasis pemecahan masalah (Project Based Learning), untuk mendorong kemampuan peserta didik untuk menghasilkan karya kontekstual, baik individual maupun kelompok. Disarankan model pembelajaran di SMK menggunakan pendekatan pembelajaran yang menghasilkan karya berbasis pemecahan masalah (Haryanto, 2010).

Project Based Learning ( $\mathrm{PjBL}$ ) adalah model pembelajaran yang berbasis produk, dimana produk dijadikan sebagai media pembelajaran (Kemendikbud, 2013). Penggunaan model PjBL pada kompetensi las listrik adalah untuk mendeskripsikan pelaksanaan pembelajaran kompetensi las listrik dengan menggunakan model PjBL, mendeskripsikan ketercapaian waktu yang dihasilkan siswa dalam membuat produk, mendeskripsikan kompetensi las listrik yang dihasilkan siswa, dan mendeskripsikan ketercapaian pembuatan produk. Tujuan penilitian ini untuk mendeskripsikan pelaksanaan pembelajaran kompetensi las listrik menggunakan model pembelajaran project based learning, mendeskripsikan ketercapaian waktu pembuatan produk, mendeskripsikan ketercapaian kompetensi las listrik dalam pembuatan produk, dan mendeskripsikan ketercapaian pembuatan produk (Hosnan, 2014).

Penelitian yang dilaksanakan dengan beberapa tahap yaitu penentuan pertanyaan mendasar, perencanaan proyek, menyusun jadwal, monitoring, menguji hasil dan evaluasi pengalaman. Ketercapaian waktu pembuatan produk yang dihasilkan seluruh kelompok dinyatakan lulus karena tidak melebihi dari alokasi waktu pembelajaran. Ketercapaian kompetensi yang dihasilkan siswa berbeda-beda. Kelompok A dan C dinyatakan lulus sedangkan kelompok B dinyatakan tidak lulus karena ketercapaian kompetensi las listrik yang didapat tidak melebihi nilai Kriteria Ketuntasan Minimum (KKM) yang ditetapkan sebagai standar ketercapaian kompetensi las. Ketercapaian pembuatan produk yang dibuat oleh kelompok A, B, dan C dinyatakan tidak lulus karena hasil ketercapaian pembuatan produk yang di hasilkan siswa tidak ada yang melebih nilai (KKM) yang ditetapkan sebagai standar ketercapaian pembuatan produk (Brahmantyo, 2012).

Project Based Learning merupakan model pembelajaran yang menitik beratkan pada suatu proyek/produk sebagai hasil pembelajaran. Pembelalajaran PjBL memberikan kesempatan kepada siswa untuk secara aktif, inovatif, mandiri mencari dan menggabungkan berbagai informasi, merancang, merencanakan serta membuat suatu pruduk bernilai dan realistic (Huda, 2014). Model pembelajaran Project Based Learning memiliki karakteristik sebagai berikut: peserta didik mementukan sendiri proyek/produk yang akan dibuat, merancang dan mendesain produk yang dibuat, menyusun jadwal 
kegiatan pembuatan produk, guru memonitoring kegiatan yang dilakukan peserta didik selama pengerjaan proyek/produk, guru dan peserta didik secara bersama-sama menguji hasil produk yang yang dibuat peserta didik, guru dan peserta didik secara bersama-sama mengevaluasi baik sikap, proses kerja, kegiatan kerja, dan hasil produk yang dibuat siswa, dan hasil akhir dari pembelajaran berupa sebuah produk yang memiliki nilai guna.

Keunggulan dari pembelajaran dengan menggunakan model pembelajaran Project Based Learning sebagai berikut: peserta didik dapat lebih aktif dalam proses pembelajaran, pengalaman yang didapat lebih nyata dengan dunia kerja, keterampilan yang didapat peserta didik tidak semata keterampilan yang berkaitan dengan mata pelajarannya saja, peserta didik bisa mendapatkan keterampilan lain yang tidak diajarkan oleh sekolah. Proses pembelajaran lebih terasa seperti pada dunia kerja dimana teman lebih seperti rekan kerja. Peserta didik dapat memecahkan masalah yang lebih kompleks selama pengerjaan proyek (Riyanto, 2010).

Kekurangan dari pembelajaran dengan menggunakan model pembelajaran Project Based Learning adalah waktu yang dibutuhkan untuk mengerjakan proyek/produk terbilang lama, biaya untuk membuat proyek/produk terbilang memerlukan biaya yang besar, dan alat dan mesin (media) yang digunakan terbilang banyak.

\section{METODE PENELITIAN}

Metode penelitian yang gunakan pada penelitian ini ialah metode eksperimen dengan bentuk pre-experimental dengan desain one shot case study. Menurut Sugiyono (2013, hlm. 109-110) pre-exsperimental merupakan eksperimen yang belum sungguh-sungguh, dikatakan belum sungguh-sungguh dikarekan masih terdapat variabel luar yang ikut berpengaruh terhadap terbentuknya variabel terikat. Hasil eksperimen yang merupakan variabel terikat bukan semata-mata dipengaruhi oleh variabel bebas. Hal ini terjadi karena tidak adanya variabel kontrol dan sampel tidak dipilih secara acak. Makna desain penelitian adalah terdapat suatu kelompok peserta didik yang diberikan treatment/perlakuan, dan selanjutnya diobservasi hasilnya (treatment adalah sebagai variabel bebas dan hasil adalah sebagai variabel terikat).

\section{HASIL PENELITIAN}

Kegiatan peserta didik selama pembuatan produk dihitung lama waktu pengerjaan pada masing-masing kelompok. Rata-rata waktu pengerjaan Meja TV adalah 2067 menit, 
dan rata-rata waktu pengerjaan dalam kelompok yaitu 689 menit. Hasil penelitian telah diperoleh dan diringkas pada Tabel 1, 2 dan 3.

Tabel 1. Ketercapaian waktu pembuatan produk pengelasan

\begin{tabular}{cccc}
\hline \multirow{2}{*}{ Kegiatan } & \multicolumn{3}{c}{ Waktu (menit) } \\
\cline { 2 - 4 } & $\mathrm{A}$ & $\mathrm{B}$ & $\mathrm{C}$ \\
\hline Marking (Penandaan) & 55 & 60 & 52 \\
Pemotongan & 125 & 115 & 108 \\
Pengelasan & 403 & 383 & 346 \\
Penggerindaan & 46 & 30 & 50 \\
Pendempulan & 28 & 26 & 23 \\
Pengamplasan & 35 & 39 & 42 \\
Pengecatan & 26 & 29 & 46 \\
Total Waktu & 718 & 682 & 667 \\
\hline
\end{tabular}

Ketercapaian kompetensi las listrik yang dilakukan peserta didik dalam membuat produk Meja TV sudah termasuk baik.

Tabel 2. Ketercapaian kompetensi las listrik

\begin{tabular}{ccccc}
\hline \multirow{2}{*}{ Kegiatan } & Skor & \multicolumn{3}{c}{ Ketercapaian Kompetensi Las Listrik } \\
\cline { 3 - 5 } & Maksimal & $\mathrm{A}$ & $\mathrm{B}$ & $\mathrm{C}$ \\
\cline { 3 - 5 } Proses kerja pengelasan & 93 & 70 & 67 & 71 \\
Presentase Pencapaian (\%) & 100 & $75,26 \%$ & $72,04 \%$ & $76,34 \%$ \\
\hline
\end{tabular}

Tabel 3. Ketercapaian Pembuatan Produk

\begin{tabular}{|c|c|c|c|c|c|}
\hline \multirow{2}{*}{ Kegiatan } & \multirow{2}{*}{$\begin{array}{c}\text { Skor } \\
\text { Maksimal }\end{array}$} & \multirow{2}{*}{ Bobot } & \multicolumn{3}{|c|}{ Ketercapaian Pembuatan Produk } \\
\hline & & & A & $\mathrm{B}$ & $\mathrm{C}$ \\
\hline 1. Pengelasan & 93 & $50 \%$ & 70 & 67 & 71 \\
\hline \multicolumn{3}{|c|}{ Persentase ketercapaian } & $37,63 \%$ & $36,02 \%$ & $38,17 \%$ \\
\hline 2. Penandaan & 31 & \multirow{6}{*}{$30 \%$} & 31 & 31 & 31 \\
\hline Pemotongan & 33 & & 33 & 33 & 33 \\
\hline Penggerindaan & 13 & & 12 & 12 & 12 \\
\hline Pendempulan & 7 & & 6 & 5 & 6 \\
\hline Pengamplasan & 12 & & 11 & 11 & 11 \\
\hline Pengecatan & 18 & & 16 & 16 & 16 \\
\hline Total ketercapaian & 114 & & 109 & 108 & 109 \\
\hline \multicolumn{3}{|c|}{ Persentase ketercapaian } & $28,68 \%$ & $28,42 \%$ & $28,68 \%$ \\
\hline 3. Hasil Kerja & 3 & $20 \%$ & 1 & 1 & 1 \\
\hline \multicolumn{3}{|c|}{ Persentase ketercapaian } & $6,66 \%$ & $6,66 \%$ & $6,66 \%$ \\
\hline \multicolumn{2}{|c|}{$\begin{array}{l}\text { Hasil ketercapaian pembuatan } \\
\text { produk }\end{array}$} & $100 \%$ & $72,97 \%$ & $71,10 \%$ & $73,51 \%$ \\
\hline
\end{tabular}




\section{PEMBAHASAN}

Pertanyaan yang diajukan guru seputar pelaksanaan kompetensi las listrik dengan model Project Based Learning seperti pentayaan produk apa yang dapat dibuat dengan proses pengelasan las listrik?, produk las apa yang digunakan dalam kehidupan seharihari?, dan bagaimana cara membuat produk tersebut dengan proses pengelasan?, masih banyak siswa yang mengalami kesulitan dalam membayangkan/menentukan produk pengelassan yang akan dibuat, peran guru dibutuhkan dalam membimbing siswa sehingga dapat menentukan produk yang akan dibuat. Pemilihan pembuatan produk Meja TV dikarenakan melihat di kehidupan sehari-hari Meja TV diperlukan, dan dalam penggunaannya Meja TV tidak hanya bisa digunakan untuk TV saja tetapi bisa digunakan untuk hal lain seperti menyimpan buku.

Siswa mengalami kesulitan saat mendesain perencanaan proyek seperti merencakan bahan, alat, cara pembuatan dan biaya yang dibutuhkan, kesulitan terjadi dikarenakan siswa baru pertama kali membuat sebuah produk pada pembelajaran kompetensi las, untuk itu peran guru diperlukan untuk memberikan gambaran dengan mendiskusikan bersama siswa dalam merencakan bahan, alat, cara pembuatan dan biaya yang dibutuhkan untuk membuat produk Meja TV.

Menyusun jadwal dilakukan dengan cara mendiskusikan antara guru dan siswa. Pada pembelajaran kompetensi las listrik siswa baru pertama kali membuat sebuah produk sehingga siswa kesulitan dalam menetukan target waktu penyelesaian pembuatan produk Meja TV.

Monitoring yang dilakukan guru selama pengerjaan produk Meja TV untuk mengetahui sejauh mana kegiatan yang dilakukan siswa, seringkali siswa kesulitan dalam melakukan suatu kegiatan contohnya saat pengelasan dinding Meja. manfaat monitoring yang dilakukan guru, guru dapat mengetahui sejauh mana kemampuan siswa dan saat siswa mengalami kesulitan guru dapat memberikan cara/solusi untuk memecahkan masalah/kesulitan yang dihadapi siswa.

Produk Meja TV yang dihasilkan siswa selanjut dilakukan pengujian sesuai dengan aspek indikator yang telah ditentukan, karena ini merupakan produk pertama yang dibuat siswa pada pembelajaran kompetensi las listrik maka hasilnya pun bisa dikatakan tidak terlalu baik, karena saat dilakukan pengujian hasil Meja TV, Meja TV masih ada yang miring dan bergoyang namun saat diberi beban Meja TV ini mampu menahan beban yang diberikan. 
Hasil produk Meja TV yang dibuat oleh siswa dievaluasi baik dari aspek sikap, proses, dan hasil produk Meja TV. Evaluasi yang dilakukan guru dan siswa bertujuan agar siswa mengetahui sejauh mana proses dan hasil produk yang dibuat siswa, agar kekurangan yang dimiliki siswa dapat diperbaiki secara bersama-sama maupun secara individu. Pelaksanaan pembelajaran kompetensi las listrik dengan menggunakan model pembelajaran Project Based Learning mengalami hambatan, hambatan yang terjadi diantaranya pada awal kegiatan pembelajaran kompetensi las listrik siswa mengalami gugup/kebingungan dikarenakan siswa baru merasakan pembelajaran dengan model Project Based Learning, dan guru yang canggung karena metode yang biasa digunakan sebelumnya bersifat teacher center berubah menjadi student center.

Model pembelajaran Project Based Learning yang dilaksanakan pada pembelajaran kompetensi las listrik mempunyai kekurangan. Pembelajaran kompetensi las listrik diantaranya pembuatan produk membutuhkan waktu yang terbilang banyak, biaya yang dibutuhkan untuk satu produk tergolong besar, dan alat yang digunakan untuk pembuatan produk tidak hanya cukup dengan mesin las listrik saja (Slameto, 2010).

Kelebihan dari model pembelajaran Project Based Learning pada pembelajaran kompetensi las listrik yang dilaksanakan pada penelitian ini adalah suasana pembelajaran yang berawal dari berpusat pada guru (teacher center) mengalami perubahan menjadi berpusat pada siswa (student center), siswa mendapatkan pengalaman nyata akan dunia kerja tentang pengelasan las listrik, siswa menikmati proses pembuatan produk terlihat dari semangatnya saat mengerjakan pembuatan produk Meja TV, siswa lebih aktif, hasil pembelajaaran berupa produk dapat digunakan selain itu juga produk memiliki nilai jual, dan keterampilan yang didapat siswa tidak hanya keterampilan mengelas las listrik saja bahkan mendapatkan keterampilan lain yang tidak diajarkan seperti keterampilan mengecat.

Agar pelaksanaan pembelajaran dengan model Project Based Learning pada pembelajaran kompetensi las listrik sesuai dengan yang diharapkan sekolah. Memenuhi berbagai prasyarat diantaranya alokasi waktu pembelajaran yang harus cukup untuk pembuatan produk, alokasi biaya yang dibutuhkan untuk pembuatan produk, dan alat/mesin yang sediakan tidak hanya mesin las saja tetapi membutuhkan alat/mesin seperti kompresor angin, mesin gerinda tangan, dan spray gun untuk mengecat produk yang telah dibuat (Majid, dan Firdaus, 2014).

Waktu yang dicapai oleh kelompok peserta didik dengan nilai atas (kelompok A) untuk mengerjakan proyek Meja TV adalah 718 menit, kelompok peserta didik dengan 
nilai sedang (kelompok B) adalah 682 menit, dan peserta didik dengan nilai bawah (kelompok C) adalah 667 menit. Rata-rata waktu pengerjaan Meja TV seluruh kelompok adalah 11 jam 48 menit atau setara dengan 689 menit. Berdasarkan alokasi standar waktu yang telah ditetapkan pada silabus yaitu selama 848 menit, maka hasil dari ketercapaian waktu pengerjaan proyek yang telah dicapai oleh masing-masing kelompok, kelompok A, B, dan C dinyatakan lulus dalam waktu penyelesaian produk Meja TV karena ketiga kelompok tersebut tidak melebihi dari alokasi waktu pembelajaran (Tessmer, 1998).

Ketercapaian kompetensi las listrik yang dicapai oleh kelompok peserta didik dengan nilai atas (kelompok A) untuk mengerjakan produk Meja TV adalah 75,26\% (jika dikonversikan kedalam bentuk nilai adalah 75,26), kelompok peserta didik dengan nilai sedang (kelompok B) adalah 72,04\% (72,04), dan peserta didik dengan nilai bawah (kelompok C) adalah 76,34\% (76,34). Berdasarkan batas nilai ketuntasan (KKM) yang ditetapkan pada mata pelajaran Mekanika Teknologi khususnya materi pokok Las Lsitrik yaitu 75, maka nilai yang didapatkan oleh kelompok A dan $\mathrm{C}$ dinyatakan lulus. Kelompok $\mathrm{B}$, dinyatakan tidak lulus karena nilai yang didapat belum melewati batas nilai ketuntasan (Primardiana, 2013).

Ketercapaian hasil pembuatan produk Meja TV oleh peserta didik dengan nilai atas (kelompok A) adalah 72,97\%, ketercapaian pembuatan produk oleh peserta didik dengan nilai sedang (kelompok B) adalah $71,10 \%$, dan ketercapaian pembuatan produk oleh peserta didik dengan nilai bawah (kelompok C) adalah 73,51\%. Berdasarkan batas nilai ketuntasan (KKM) yang ditetapkan pada mata pelajaran Mekanika Teknologi khususnya materi pokok Las Lsitrik yaitu 75. Nilai yang didapatkan oleh kelompok A, B dan C dinyatakan tidak lulus, dinyatakan tidak lulus karena nilai yang didapat belum melewati batas nilai ketuntasan (KKM).

\section{KESIMPULAN}

Ketercapaian waktu yang dihasilkan siswa dalam pembuatan produk pengelasan sebagai kompetensi las listrik dengan model pembelajaran Project Based Learning ratarata waktu yang dicapai dari setiap kelompok adalah 689 menit. Seluruh kelompok dinyatakan mencapai ketercapaian waktu (lulus). Ketercapaian kompetensi las listrik yang dihasilkan siswa dalam pembuatan produk pengelasan berbeda-beda tetapi didominasi dengan lebih banyaknya kelompok yang lulus \& dinyatakan dapat mencapai ketercapaian kompetensi las listrik. Tidak ada kelompok yang dinyatakan dapat mencapai ketercapaian pembuatan produk. 


\section{DAFTAR PUSTAKA}

Abidin, Y. (2014). Desain Sistem Pembelajaran Dalam Konteks Kurikulum 2013. Bandung: RefikaAditama.

Aunurrahman. (2013). Belajar dan Pembelajaran. Bandung: Alfabeta.

Brahmantyo, D. (2012). Desain Las (WeldingDesign). Departemen Metalurgi \& Material Teknik: Fakultas Teknik Universitas Indonesia.

Haryanto. (2010). Macam-Macam Teori Mengajar. [Online]. Tersedia: http://belajar psikologi.com/macam-macam-teori-belajar/. [diakses: 20 Juni 2015].

Hosnan. (2014). Pendekatan Saintifik dan Kontekstual Dalam Pembelajaran Abad 21. Jakarta: Ghalia Indonesia.

Huda, M. (2014). Model-model Pengajaran dan Pembelajaran. Yogyakarta: Pustaka Pelajar.

Kemendikbud. (2013). Materi Pelatihan Guru Implementasi Kurikulum 2013. Jakarta: Kemendikbud.

Majid, A. dan Firdaus, A. (2014). Penilaian Autentik Proses dan Hasil Belajar. Bandung: Interes Media.

Primardiana, dkk. (2013). Model Evaluasi Pembelajaran Berbasis Kaizen di Sekolah Menengah Atas. Jurnal Penelitian dan Evaluasi Pendidikan.

Riyanto, Y. (2010). Paradigma Baru Pembelajaran. Jakarta: Kencana Predana Media Grup.

Slameto. (2010). Belajar dan Faktor-Faktor yang Mempengaruhinya. Jakarta: PT Rineka Cipta.

Tessmer. (1998). Planningand Conducting Formative Evaluations. Philadelphia: KoganPage. 